\title{
PSYCHE
}

VOL. XVII.

DECEMBER, 1910.

No. 6

\section{THE AQUATIC CATERPILLARS OF LAKE QUINSIGAMOND.}

\author{
By Wм. T. M. Forbes. \\ Worcester, Mass.
}

Lake Quinsigamond is situated in the center of Massachusetts, on the boundary between Worcester, Shrewsbury, and Grafton. It is long, resembling a river, with a number of shallow inlets, especially along the east shore. The main part of the lake is clear of vegetation, and most of the inlets have been disturbed by man, but beyond the "Stringer Dam," which cuts off the southeast corner, and in Flint's Pond, which is in all but name the south end of the lake, the water is mostly only three or four feet deep, and overgrown with the water lilies, Nymphæa and Castalia, Floating Shield, Floating Heart, Pond-weeds, Bladderworts, Pickerel weed, Elodea, and many other plants. This part swarms with Nymphulæ, of the following species:

N. maculalis, common especially over waterlilies, but flying freely and often found even on shore; also ab. masculinalis.

N. seminealis, equally common where Limnanthemum (Floating Heart) is dominant.

$N$. obscuralis. A single specimen.

$N$. allionealis, rather rare, and found only at a single spot, on the north shore of "Cuba" Island.

$N$. badiusalis, earlier than the preceding, except perhaps the last, and found mostly nearer shore; not very common.

$N$. gyralis, common, especially in Flint's Pond.

N. icciusalis, quite common.

Pyrausta nelumbialis, not common.

Larvæ were found of four species; maculalis and seminealis in large numbers, two of gyralis (?); and one of icciusalis.

Generic characters of the caterpillar. N. (Nymphoeella) maculalis may be taken as a type, but obscuralis and gyralis (?) were com- 
pared, also nymphaata of Europe. Head somewhat wider than high; small compared with width of body; front somewhat higher than wide, reaching more than two-thirds way to the vertex; the setæ far apart and high up, the punctures only a third as far apart as the setæ, and much lower; adfrontals slender, not entirely well defined from the epicrania; reaching vertex, but not quite completely separating front from epicrania below, with setæ close together and decidedly below the puncture. Labrum with $i i$ rather higher than $i$, iii much below $i v$, moderately notched. Epicrania with $i i$ near to adfrontals; with five ocelli, the posterior one being wanting. Antennæ with second joint four to seven times as long as wide, longer in Nymphæella and Paraponyx than in Hydrocampa, with one seta at about two-thirds its length, the long seta only about three-fifths as long as the joint; third and fourth joints equally long. Body very variable in shape in life, when preserved, short and broad, with tracheal gills in the subgenera Nymphæella and Paraponyx. Ventral prolegs rudimentary, with an ellipse of crotchets, alternatelyof two or three lengths, hardly interrupted in the first two genera, but broadly interrupted at the inner and outer ends in Hydrocampa. Anal prolegs with an ellipse of hooks in the former, broadly interrupted behind; in the latter, a single short straight band.

Spiracles of segments A2, 3, and 4, enlarged, the others rudimentary.

1. N. (Nymphceella) maculalis was very common wherever either of the waterlilies grew, and for some distance about on the shore males were plentiful. The male varied but little; but of the female, beside the typical ash-gray form some were pale brown, marked almost as in female obscuralis or with dark bands; some were gray with paler costa; and one or two white, with a few fragments of black lines (ab. masculinalis). Plenty of caterpillars were bred; and they are undoubtedly those noted by Dyar as gyralis (?).

The caterpillar forms a nest on leaves of the two waterlilies, Castalia and Nymphæa (Nuphar), and also on Brasenia, by cutting out a piece of the margin, and attaching it by silk to either the upper or under surface of the leaf. This nest is a broad oval, and when full sized is about an inch to an inch and a half long, and forms a rounded hump in the leaf when on the under side. (These were caterpillars of the first brood, in July.) When taken into 
the house, into warmer water, they mostly cut out the portion of leaf on which their nests were made, and so made of then portable cases, much like those of $N$. gyralis, but filled with water. Pupation took place in the last nest, which was lined with a translucent layer of silk, and then showed a distinct central ridge from the outside. If the caterpillar was in a portable case (in the laboratory), it was anchored to the edge of a leaf. Late in August young caterpillars about an eighth of an inch long, or a little larger, had the same habits, but very soon the cases were cut away, as happened with the first brood in the laboratory, and the caterpillars were found to be only on the young submerged leaves. Apparently when very young they eat one epidermis and the parenchyma of the parts of the leaf forming their nests, but by the time they are a quarter of an inch long they feed only outside of the nest which is of uninjured pieces of leaf.

Eggs were laid in captivity, but not in a regular egg-mass. They were oval and flattened; $.65 \times .5 \mathrm{~mm}$., and had no decided longitudinal ridge. Duration of stage about ten days.

Stage I. (From these eggs.) Slightly larger than N. gyralis? described below, with proportionately much larger anal setæ, without a trace of gills. Head nearly $.3 \mathrm{~mm}$.; length of large anal setæ $1 \mathrm{~mm}$.

Stage II. Not seen; and no sign of leaf-mining was noticed.

Stage III (?). A transparent caterpillar, essentially like the full-grown ones. The maximum number of gill-filaments is two, and the anterior suprastigmatals and the last three pedals have but one. Length about $4 \mathrm{~mm}$; head $.6 \mathrm{~mm}$.

Stage IV. Length 4 to $6 \mathrm{~mm}$; head .4 to $.56 \mathrm{~mm}$.; maximum number of gillfilaments three.

Stage $V$. Length 6 to $10 \mathrm{~mm}$; head 1 to $1.5 \mathrm{~mm}$.; maximum number of gillfilaments four. (Possibly two stages are confused here, or the wide range in size of head may be sexual.

Last Stage. Length fully extended may reach $25 \mathrm{~mm}$; head $1.5 \mathrm{~mm}$. Transparent, the only appearance of marks being due to the internal organs showing through. Head pale chitin-yellow, with darker mouth-parts. The gills are 100 in number, each with from two to five filaments, as shown in the diagram.

$\begin{array}{llllllllllll}\text { Segments. } & \text { T2 } & 3 & \text { A1 } & 2 & 3 & 4 & 5 & 6 & 7 & 8 & 9\end{array}$

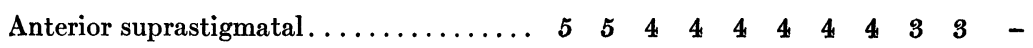

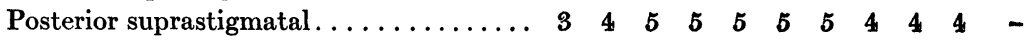

Lateral........................ 33

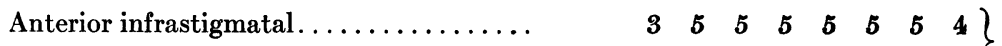

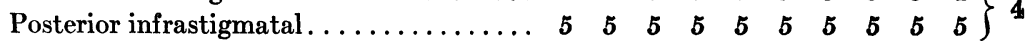

Pedal........................... 
The characters that distinguish $N$. maculalis from $N$. obscuralis are, then, the equal number of filaments on the anterior and posterior infrastigmatals, and the fact that the seventh abdominal segment has one less pedal gill-filament than the more anterior ones. The filaments are also proportionately longer and the unbranched basal portion is longer. These characters will hold at least as early as the stage with two gill-filaments. From Hydrocampa gyralis (?) and icciusalis, it can be easily distinguished by the gills, and also by the spiracles, of which those on segments, 2-4, of the abdomen are equal, but minute (the size of the smallest in $N$. gyralis (?); and that of the first segment and the posterior ones are equal and rudimentary. The caterpillar becomes pale yellow just before pupation. Food Nymphæaceæ.
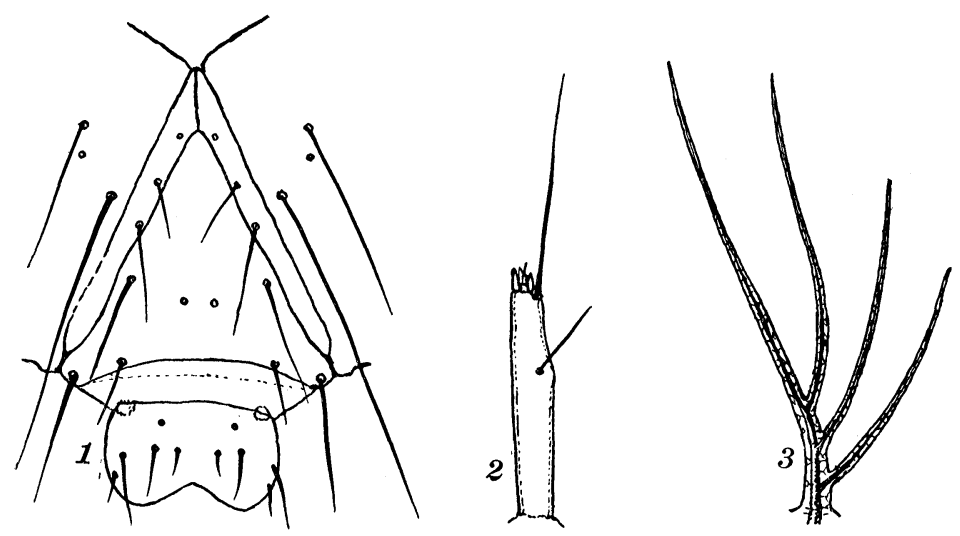

Fig. 1. Front and labrum of Nymphula maculalis.

Fig. 2. Antenna of $N$. maculalis.

Fig. 3. Tracheal gill of Nymphula.

Pupa similar in general form to that of obscuralis, as described by Dyar, but of the seven ridges near the tip of the abdomen beneath, only the central one remains, and the anal opening is not distinctly Y-shaped. The case for the hind legs varies considerably in length.

2. N. seminealis. Was not quite so common as the last; and the males did not rove as widely. No specimens were taken far from Limnanthemum.

$\sigma^{7}$. Whitish, powdered with dark brown, giving a chocolate brown effect. Transverse posterior line broad, even and white, strongly contrasting; running from the 
costa to the submedian space, and then turning inward as far as the middle of the wing; preceded by an equal band of brilliant bronze. Subterminal fine, even, black, not reaching either costa or inner edge, and preceded by a broader line of grayish white. Subterminal space dark bronze; terminal space tawny, with a golden reflection. Fringe lead-colored. Hind wing not differing from that of the female. The wings are rather broader.

ㅇ. Groundcolor, dull tawny brown, about the color of the subterminal space of the male, but not brilliantly bronzy. T. p. band grayish, not contrasting, subterminal line preceded by a less brilliant gray band; wings narrower.

Seminealis is an exceedingly close relative of $N$. obscuralis and badiusalis, and if juncealis is equally close, as Guénée's figure would suggest, Oligostigma will have to be widened to include the two former species, and will at best be a very subordinate subgenus of Nymphula, group Paraponyx. The slight truncation of the hind wings, given in the definition of Oligostigma, is shared by the other two. Vittatalis and the East Indian species have, however, ${ }^{1}$ quite a different appearance.

Caterpillars were common, and were bred through. They come nearest to those of $N$. obscuralis, described by Hart, but the adult caterpillar has but four filaments to a gill, while maculalis has six. They have also a different food-plant; and none were found on Potamogeton which is common intermingled with the Limnanthemum. Four stages were seen, and the first was probably missed, as the head of the smallest found was too large for a normal Nymphula egg. It will probably resemble those of maculalis and gyralis (?) and be without gills.

Stage II. Maximum number of filaments one; width of head $4 \mathrm{~mm}$. At this stage the caterpillar is a leaf-miner, lying close to the lower epidermis, and forms a somewhat trumpet-shaped mine.

Stage III. Maximum number of filaments two, the anterior subdorsals and stigmatals with but one; head $.7 \mathrm{~mm}$. The caterpillar now removes the lower epidermis as well as the parenchyma, and covers itself with a fragment of leaf. It forms a path continuous with its previous mine.

Stage IV. Maximum number of filaments three; head $.9 \mathrm{~mm}$. A case is now formed between a leaf and a piece cut out, or between two neighboring leaves. The red lower surface is eaten in a series of bands within the nest, forming a very characteristic marking; a habit which persists till the caterpillar is full grown, unlike maculalis, which after an early stage does not feed within the nest.

Last Stage. Maximum number of filaments four; head $1.3 \mathrm{~mm}$. Habits as in the preceding stage, but the case is more often made between two complete leaves,

II am indebted to Mr. W. D. Kearfott for the opportunity of seeing specimens of this genus. 
or is occasionally detached and carried about, especially in captivity. In my full grown caterpillars the filaments were arranged as follows:

Segment.

Anterior suprastigmatal. . . . . . . . . .

Posterior suprastigmatal. . . . . . . .

Lateral . . . . . . . . . . . . . . . . .

Anterior infrastigmatal...........

Posterior infrastigmatal. ..........

Pedal.

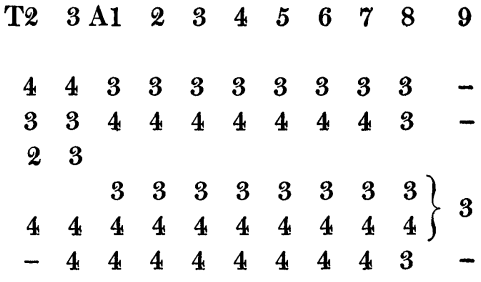

From $N$. maculalis it may be distinguished by the fact that the anterior infrastigmatal has constantly one less filament than the posterior; and that the number of filaments in the pedal row is not reduced until the last one if at all. This distinction holds in the two-gilled and all later stages, and also applies to the other members of the subgenus, obscuralis and stratiotata.

Food Limnanthemum; will eat Potamogeton in captivity.

The pupa seems identical with that of $N$. obscuralis; but the hindleg case is quite variable, sometimes as long as the body.

3. N. obscuralis. I have a single specimen of this species, caught at Worcester, but probably not coming from Lake Quinsigamond.

Ground color, whitish powdered with black-brown like male seminealis, but even duller, the powdering forming a darker median shade. T. p. line white, narrow, forming deep inward cusps opposite apex of cell and on vein 4, lost below vein 4; subterminal space rather warmer brown, but terminal space concolorous. Subterminal line sharply and deeply serrate on the veins. Wings entirely without bronzy reflections, but the hind wing is marked exactly as in $N$. seminealis.

4. N. badiusalis. Not common, with $N$. allionealis, and nearer shore. The caterpillar may possibly feed on some submerged plant.

5. $N$. allionealis. Not common, and only in a single station. Judging by the related European species stratiotata the caterpillar will feed on such a plant as Elodea, and will have one more filament in the posterior subdorsal gills than in either of the infrastigmatals.

6. N. gyralis. Was common enough, especially in Flint's Pond, to the south of the lake proper. It was the only member of its group (typical Hydrocampa) that was seen at the lake, so I place 
with it, with some doubt, the following early stages. At any rate they do not seem to belong to the described species, $N$. obliteralis. The larvæ noted by Dyar as perhaps of this species are almost certainly those of $N$. maculalis.

Eggs. The eggs were quite like those of N. obliteralis, as described by Hart; $.55 \times .4 \mathrm{~mm}$.

Stage I. (From these eggs.) Head dark brown, body pale yellow, not differing from the adult; without gills. Setæ proportionately longer than later, especially those at the posterior end, the subprimaries absent. Prolegs with fifteen crotchets, all of the same length, in a transverse ellipse. The alternation of lengths evidently appears with the second stage in Nymphula. Tracheæ empty. The head seems about the same as later in structure, but the antenna apparently lacks the terminal joint. Length at hatching $2.5 \mathrm{~mm}$.; diameter of head $.2 \mathrm{~mm}$. They all died without eating, though provided with leaves of Nymphæa and Limnanthemum (laid on the latter), but they gathered on the Nymphæa leaf in numbers. Possibly in the first stage they may feed on submerged stems. Immediately on hatching they scattered and swam toward the light, spinning a tangle of silk threads.

Full-grown caterpillar. The full grown caterpillar is found in a nearly circular case, formed of two pieces of leaf of the yellow waterlily. It was large and roomy, and one piece of leaf was much larger than the other. It was filled with air. Before pupation the case was cut down to a diameter of less than $12 \mathrm{~mm}$., and was more densely lined with silk. It was left freely floating. The caterpillar did not differ in structure from that of $N$. obliteralis (Dyar); with crotchets of ventral prolegs widely interrupted inwardly and outwardly; and anal prolegs with a single short bar of 12 crotchets. It was pale yellow, with light brown head without any dark band. The first abdominal spiracle was considerably larger than the fifth, and the second was intermediate in size between the first and the third. Diameter of head $1.25 \mathrm{~mm}$.

Pupa. Deeper, brighter yellow than that of $N$. maculalis and $N$. obscuralis, the first of the open spiracles somewhat smaller than the other two. The hind leg cases reach but one third way to the tip of the body; the anal end apparently without any decided modification.

7. N. icciusalis. I had the good fortune to breed through a single specimen of this species, which was described, with some doubt, by Packard in the American Naturalist, xviii. The caterpillar is as described by him, so far as my notes go, with blackish brown head, and dirty gray body. It makes a case with decidedly rectangular shape, living the entire last stage and pupating in a single case. The figure by Packard exactly resembles my specimen. The caterpillar is extensible, like that of the other Nymphulæ and Packard's figure would represent it in full extension; when retracted it is no slenderer than the others. Before pupation the 
case is anchored beneath the water on the submerged stem, and remains there. The moth evidently swims or walks up through the water before expanding, and so is more or less amphibious. My specimen was found on Potamogeton, in comparatively deep water, and did not eat Limnanthemum, so far as I could tell, though that is much more closely related to the food plant that Packard reported, Menyanthes. It was quite surprising to find that this moth, the one generally found nearest shore, had a caterpillar just as aquatic as that of gyralis; and a pupa that is actually submerged.

8. Pyrausta nelumbialis. The caterpillar was found on yellow pond lily; in the top of the petiole.

\section{Synopsis of the Aquatic Nymphuline Caterpillars.}

With tracheal gills; second and third abdominal spiracles equal

Anterior and posterior infrastigmatal gills with the same numberof filaments...................... (subgenus Nymphæella Grote)

Maximum number of filaments five; on Nymphæaceæ........ maculalis Anterior infrastigmatal gills with one less filament

Posterior subdorsal gills with one more filament than infrastig-

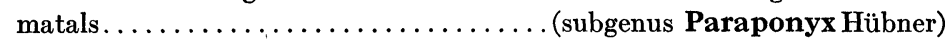

$N$. stratiotata of Europe and probably N. allionealis of America

Posterior subdorsal, and infrastigmatal, and pedal gills with the same number of filaments.............. (subgenus Oligostigma Guénée) With a maximum of six filaments in adult; usually on Vallisneria ....................... $\mathbf{N}$. obscuralis With a maximum of four filaments; usually on Limnanthemum ....................... seminealis

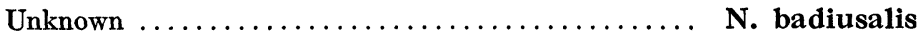

Without tracheal gills

Second abdominal spiracle decidedly smaller than the third; stout and flattened; head darker than body (subgenus Hydrocampa Latreille) Head dark chitin-yellow; in a nearly circular case

Body whitish; thoracic tubercles more distinct than abdominal ones; head with a lateral dark brown stripe; on Potamogeton ........................... obliteralis

Body pale yellow; tubercles all similar; head without dark brown except in mouth-parts; on Nuphar (Nymphæa)...N. gyralis (?)

Head dark brown; body dirty gray; in an oblong case on Potamogeton and probably Menyanthes................ N. icciusalis

Cylindrical and moniliform; head paler than body; forming a cylindrical or ellipsoidal case of a mosaic of Lemna plants. ..........Elophila The American species have not been described. 
Synopsis of the Pupa of Nymphula.

The three open spiracles equal in size; ninth abdominal segment with a median longitudinal carina below.

With but one median longitudinal carina .......... (subgenus Nymphæella

Cocoons on Nymphæaceæ................... N. maculalis

With seven longitudinal carinæ on a transverse ridge... . (subgenus Paraponyx

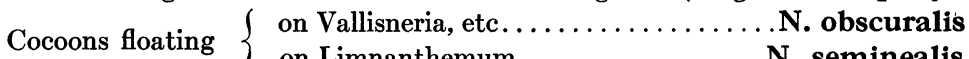

Unknown possibly submerged ........... badiusalis and $\mathbf{N}$ allionealis

The first open abdominal spiracle distinctly smaller than the other two; no distinct median carina on ninth segment below.

(subgenus Hydrocampa

Cocoon floating, nearly circular

Pupa pale yellow; first open spiracle much smaller than the other two; Potamogeton.................. obliteralis

Pupa bright yellow; first open spiracle hardly smaller than the other two; Nymphæa.................. N. gyralis (?)

Cocoon submerged, oblong; first open spiracle much smaller than the other two; on Potamogeton and Menyanthes........... icciusalis Unknown ................................ ekthlipsis

\section{Bibliography.}

Dyar, H. G.: Jour. N. Y. Ent. Soc. xiv, 77, with full bibliography, and descriptions.

Packard, A. S.: American Naturalist xviii, 824. Caterpillar of N. icciusalis.

Hart, Bull. Ill. St. Lab. Nat. Hist. iv, 167. Caterpillars of N. obscuralis and N. obliteralis.

Zool. Jahrb.: Ab. Syst. vi, 626. Caterpillars of European and exotic species.

Spuler, A.: Schm. Eur. ii, 221. The European Caterpillars. 


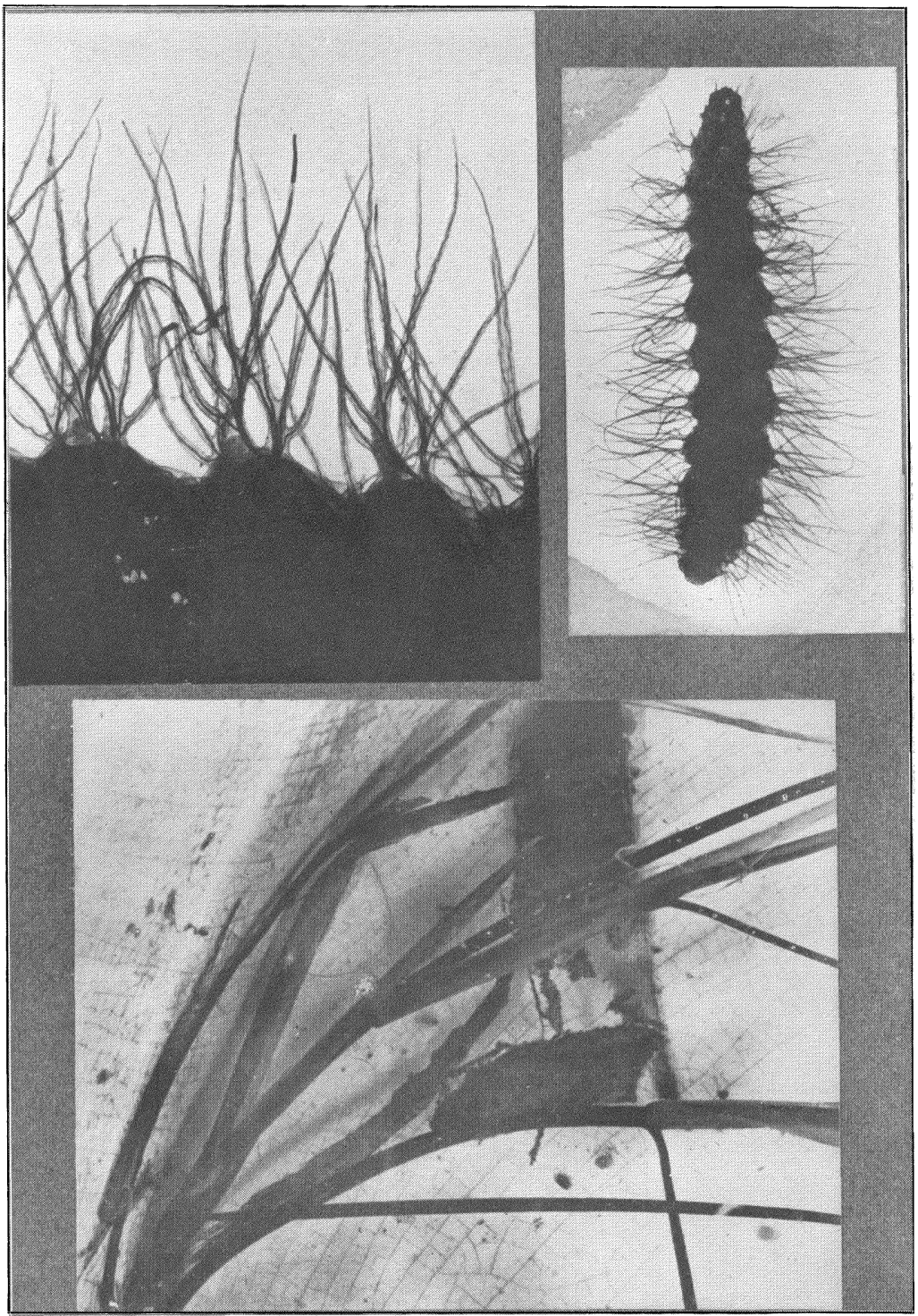

FORBES--AQUATIC CATERPILLARS.

Fig. 4. Tracheal gills of penultimate stage of $N$. maculalis, photomicrograph.

Fig. 5. Penultimate stage of $N$. maculalis seen by transmitted light; alive but stupefied with chloratone.

Fig. 6. Cocoon of $N$. icciusalis on submerged stem of Potamogeton; enlarged about two times. 

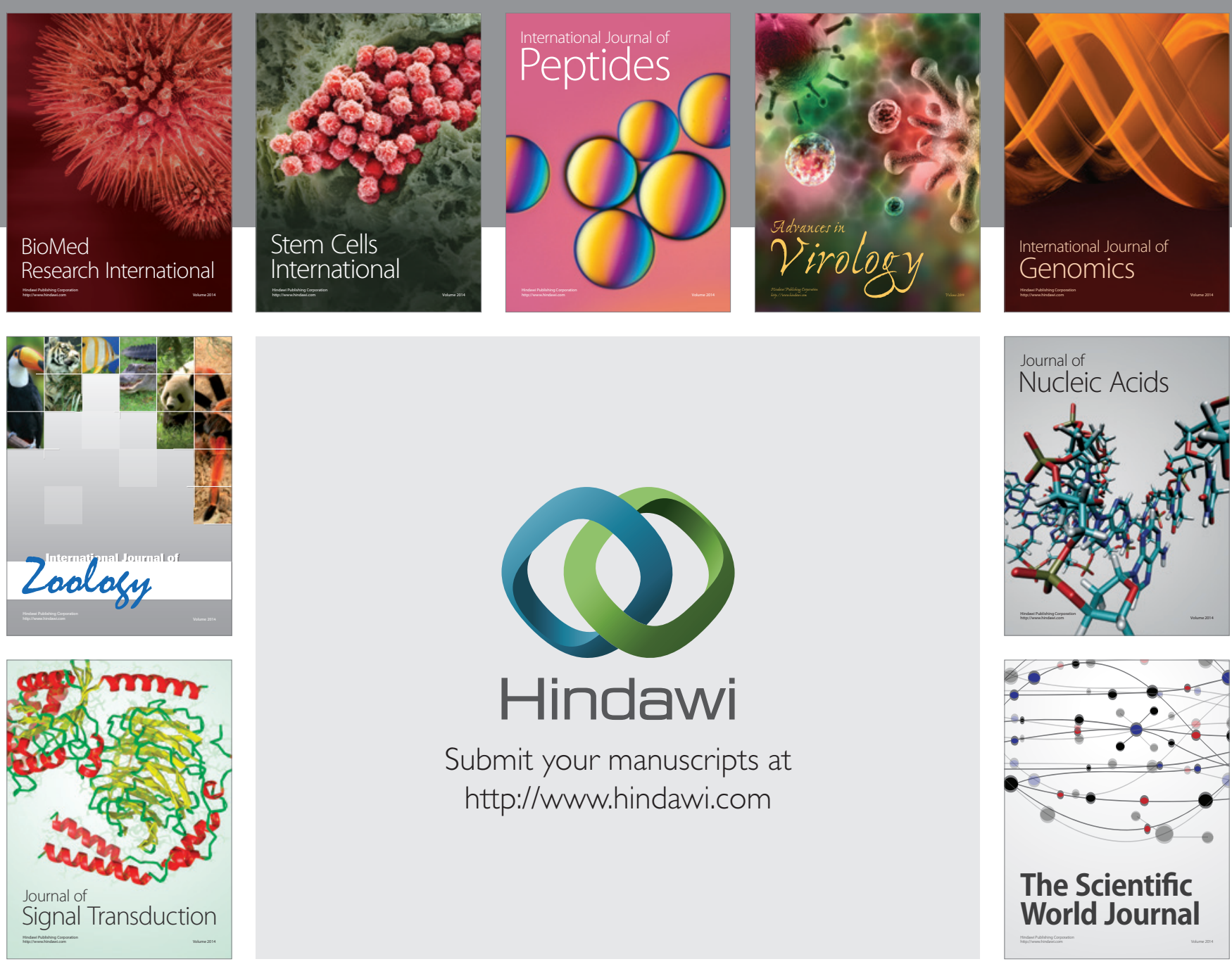

Submit your manuscripts at

http://www.hindawi.com
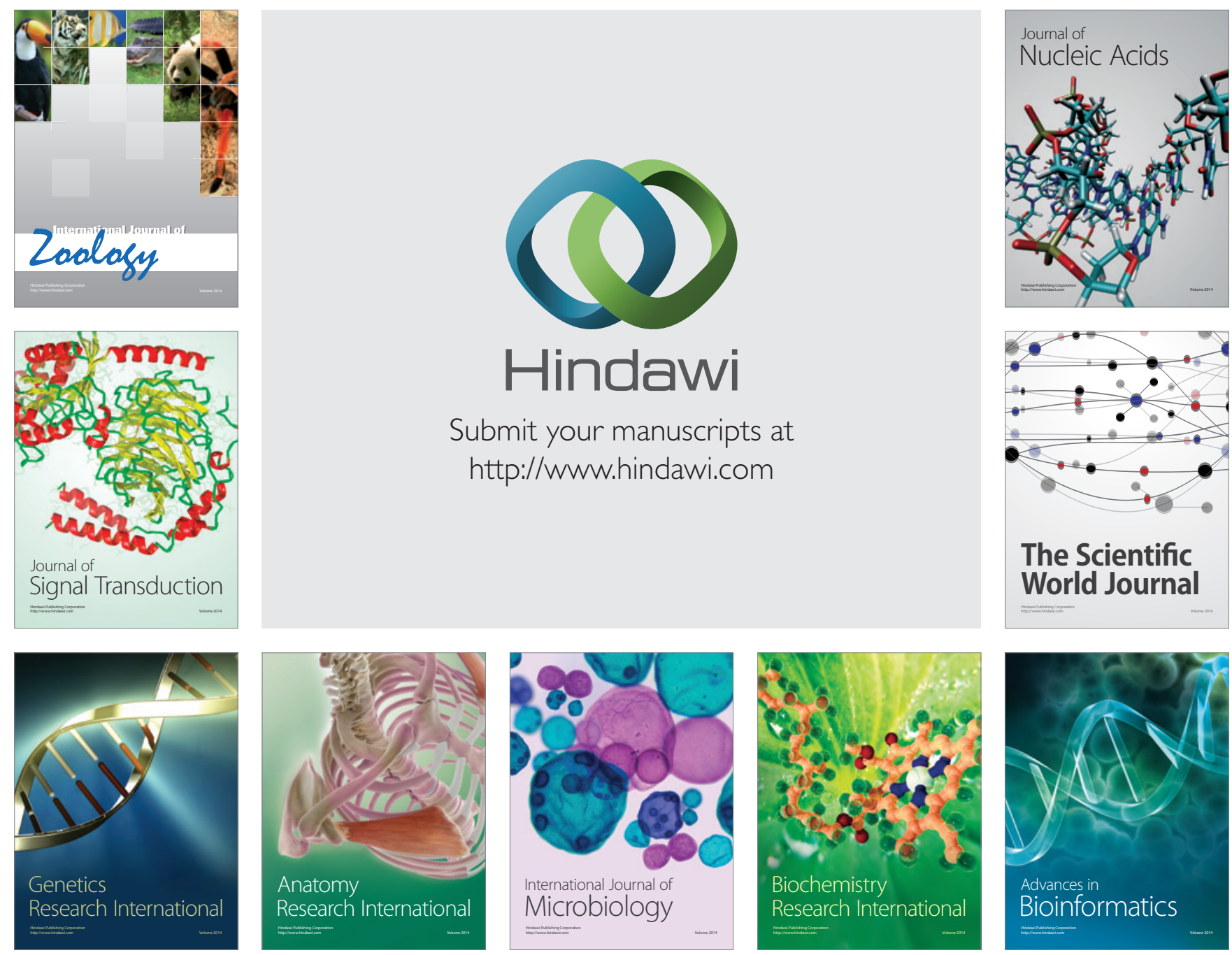

The Scientific World Journal
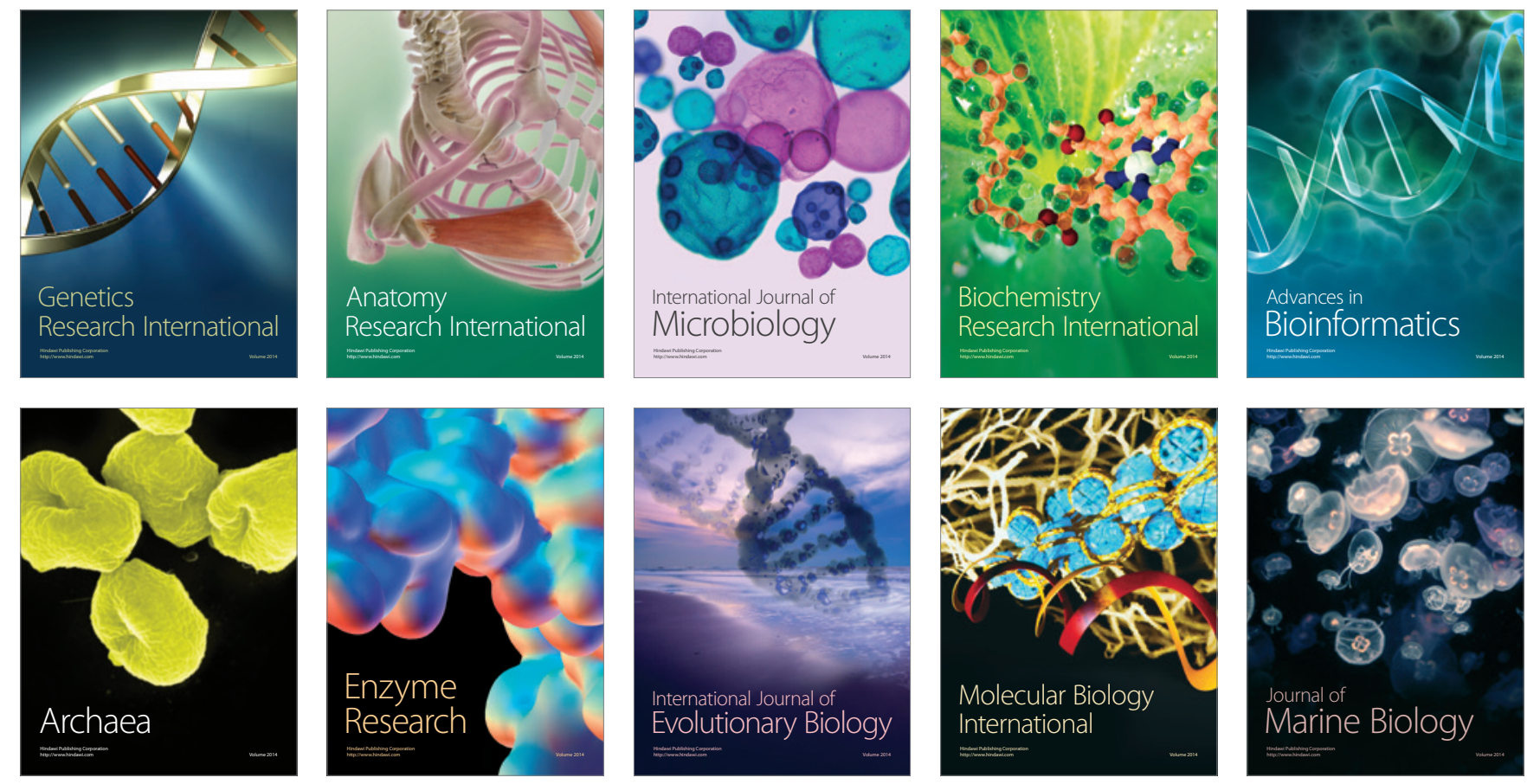